\title{
PENGGUNAAN METODE RESPON PERMUKAAN DALAM OPTIMASI METODE EKSTRAKSI KARBOHIDRAT DARI KULIT NANAS (Ananas commusus)
}

\author{
Kiki M. Yuliawati ${ }^{1}$, Suliadi ${ }^{2}$, Indra T. Maulana ${ }^{1}$, Bertha Rusdi ${ }^{1 *}$ \\ 1Program Studi Farmasi, Fakultas MIPA, Universitas Islam Bandung \\ ${ }^{2}$ Program Studi Statistika, Fakultas MIPA, Universitas Islam Bandung
}

Info Article

Submitted :

9 Agustus 2021

Revised :

17 Desember 2021

Accepted :

31 Desember 2021

\section{Corresponding Author :}

Bertha Rusdi

Email :

bertha.rusdi@unisba.ac.id

\section{ABSTRAK}

Kulit nanas seringkali menjadi limbah karena dianggap tidak bermanfaat. Padahal limbah pertanian seperti ini, seringkali masih memiliki kandungan karbohidrat yang tinggi dan juga serat pangan, yang berpotensi dimanfaatkan sebagai prebiotik. Sementara itu, proses ekstraksi merupakan tahap penting dalam pemanfaatan senyawa fitokimia karena dapat menentukan jumlah senyawa terekstraksi. Dalam penelitian ini dilakukan optimasi metode ekstraksi karbohidrat dari kulit nanas yang dilakukan secara konvensional secara pemanasan menggunakan pelarut air yang dilanjutkan dengan proses pengendapan menggunakan etanol. Metode ekstraksi dilakukan pada suhu 60,70 dan $80^{\circ} \mathrm{C}$ dengan perbandingan bahan;pelarut 1:25, 1:40 dan 1:55 dan etanol sebagai pengendap dengan konsentrasi $70 \%$, 83\% dan 96\%. Hasil analisis menggunakan metode respon permukaan menunjukkan bahwa kondisi ekstraksi yang menghasilkan kadar karbohidrat lebih tinggi dari kulit nanas terjadi pada suhu $80^{\circ} \mathrm{C}$, perbandingan bahan:pelarut 1:37 dan konsentasi pengendap etanol $96 \%$.

Kata kunci: optimasi ekstraksi, karbohidrat, kulit nanas
Access this article

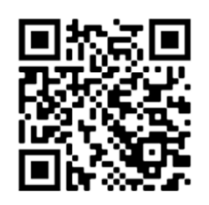

SCAN ME

\section{ABSTRACT}

Pineapple peel is often a waste because it is considered useless. Agricultural waste usually has a high carbohydrate content and also dietary fiber, which potential as a prebiotic source. Meanwhile, extraction process is an important step in the utilization of phytochemical compounds because it determine the amount of extracted compounds. In this research, the method of extracting carbohydrates from pineapple peel was carried out conventionally by heating using water as solvent followed by a precipitation process using ethanol. The extraction method was carried out at temperatures of 60,70 and $80^{\circ} \mathrm{C}$ with a ratio of $1: 25,1: 40$ and 1:55 and ethanol as a precipitate with a concentration of $70 \%, 83 \%$ and $96 \%$. Analysis result using the surface response method showed that the extraction conditions that resulted in higher carbohydrate content of pineapple peel occurred at a temperature of $80^{\circ} \mathrm{C}$, a 
material:solvent ratio of 1:37 and a precipitating concentration of 96\% ethanol.

Keywords: pineapple peel, extracting process optimization, carbohydrate

\section{PENDAHULUAN}

Tumbuhan merupakan sumber alami yang mengandung senyawa kimia (fitokimia) dalam jumlah yang sangat banyak dan juga merupakan sumber senyawa bioaktif dengan beragam struktur. Proses ekstraksi senyawa biokimia dari tumbuhan, dalam hal ini tumbuhan obat, serta estimasi secara kualitatif maupun kuantitatif akan sangat berperan penting untuk mengeksplorasi biomolekul baru. Biomolekul ini akan dapat digunakan baik dalam industry farmasi maupun agrokimia secara langsung atau sebagai senyawa penuntun (lead compound) untuk mensintesis senyawa lain yang lebih berpotensi. (Ingle et.al, 2017).

Metode ekstraksi merupakan langkah awal dalam setiap studi terhadap tumbuhan obat yang memiliki peranan penting dalam hasil akhir penelitiannya. Melalui penggunaan metode ekstraksi, dapat menarik senyawa-senyawa metabolit yang akan berperan dalam menghasilkan aktivitas farmakologi dari tumbuhan obat. Namun demikian, terdapat beberapa faktor yang dapat mempengaruhi proses ekstraksi yaitu: sifat matriks pada bagian tumbuhan, pelarut yang digunakan, suhu, tekanan dan waktu ekstraks (Azmir, J., et.al, 2013). Faktorfaktor ini akan sangat mempengaruhi hasil ekstraksi baik dalam hal rendemen maupun jenis-jenis senyawa metabolit yang tertarik ke dalam ekstrak.

Metode ekstraksi dapat dilakukan melalui berbagai prosedur esktraksi. Secara garis besar metode ekstraksi dikelompokkan menjadi metode konvensional dan non-konvensional. Metode konvensional merupakan metode ekstraksi yang menggunakan pelarut untuk menarik kandungan senyawa di dalam matriks. Sementara metode nonkovensional diketahui merupakan metode yang lebih ramah lingkungan melalui penggunaan bahan kimia sintetik dan organic yang lebih rendah, juga waktu ekstraksi yang lebih singkat dan perolehan rendemen dan kualitas ekstrak yang lebih baik (Azmir, J., et.al, 2013).

Polisakarida merupakan polimer makromolekul yang terdapat dalam jumlah melimpah di alam dan dapat diperoleh dari beberapa sumber seperti alga, tanaman dan juga mikroorganisme. Polisakarida juga memiliki peran dalam menghasilkan beberapa aktivitas farmakologi seperti antioksidan, antihiperglikemia, antitumor dan immunoregulator (Mohammed, et.al, 2021). Dalam beberapa penelitian diketahui bahwa metode ekstraksi polisakarida yang digunakan dapat berpengaruh terhadap jumlah perolehan rendemen dan juga aktivitas farmakologi yang dihasilkan. Berbagai upaya telah dilakukan untuk melihat pengaruh ekstraksi dalam hal perolehan rendemen, sifat fisikokimia dan aktivitas biologi untuk mendapatkan metode ekstraksi polisakarida yang optimal (Li, et.al, 2015).

Kulit nanas merupakan sisa yang dihasilkan dari konsumsi buah nanas. Jika dibiarkan, penumpukan kulit buah nanas ini akan menjadi limbah yang membusuk 
dan menimbulkan bau kurang sedap. Di sisi lain, kulit nanas mengandung karbohidrat dan gula yang cukup tinggi sejumlah $17,53 \%$ karbohidrat termasuk di dalamnya gula reduksi sebesar 13,65\%. Kulit nanas memiliki sejumlah glukosa dari golongan polisakarida. Termasuk dalam jenis ini adalah d-glukosamin, d-mannose, $\mathrm{d}$-xylose, l-fructose dengan perbandingan 2:2:1:1 (Utomo, 2011). Beberapa pemanfaatan limbah kulit nanas yang telah dilakukan sebagai upaya peningkatan nilai tambahnya antara lain adalah konsentrat serat, minuman serat pangan dan nata de pina (Kumalasari, et.al, 2015).

Kandungan karbohidrat dalam kulit nanas berpotensi untuk dimanfaatkan sebagai prebiotik. Terdapat penelitian mengenai pemanfaatan kulit nanas sebagai prebiotik yang ditambahkan ke dalam produk pangan fungsional telah dilakukan. Dalam penelitian yang dilakukan oleh Sah, et.al, 2015, diketahui bahwa penambahan $1 \% \mathrm{~b} / \mathrm{v}$ serbuk kulit nanas pada produk yogurt, dapat meningkatkan pertumbuhan $L$. acidophilus, L. casei dan L. paracasei. Kemampuan serbuk kulit nanas pada konsentrasi $1 \% \mathrm{~b} / \mathrm{v}$ dalam meningkatkan pertumbuhan bakteri Lactobacilli juga dilaporkan oleh Diaz-Vela et al. (2013).

Metode permukaan respon merupakan metode statistika dan matematika yang digunakan secara luas untuk mendapatkan pemodelan dan menganalisis proses yang dipengaruhi oleh beberapa variable (Aydar, 2018). Sebagai ilustrasi, dalam menghasilkan rendemen ekstrak, metode ekstraksi dapat dipengaruhi oleh berbagai faktor, diantaranya adalah suhu dan perbandingan bahan:pelarut. Dengan menggunakan metode permukaan respon dapat ditentukan kondisi suhu dan perbandingan pelarut yang memberikan rendemen ekstrak yang optimal.

Dalam penelitian ini, dilakukan penggunaan desain penelitian 3 faktor, dalam hal ini suhu ekstraksi, perbandingan simplisia: pelarut dan kadar etanol sebagai pengendap yang digunakan untuk mengekstraksi polisakarida dari kulit nanas. Data yang diperoleh kemudian dianalisis menggunakan Metode Permukaan Respon untuk mendapatkan kondisi optimum mendapatkan rendemen ekstrak.

\section{METODE PENELITIAN}

Dalam penelitian ini, bahan kulit nanas diperoleh dari daerah Cirangkong, Kabupaten Subang. Tahapan penelitian terdiri dari pembuatan simplisia, penapisan fitokimia, ekstraksi karbohidrat, pengendapan polisakarida dan pengukuran kadar glukosa menggunakan metoda fenol-asam sulfat.

\subsection{Alat dan Bahan}

Kulit nanas yang digunakan diperoleh dari daerah Subang, Jawa Barat. Pelarut dan bahan kimia yang digunakan adalah etanol (Bratachem, grade teknis), asam sulfat pekat (Merck, pro analisa), fenol (Merck, pro Analisa), glukosa (Merck) dan akuades (Brataco). Peralatan yang digunakan adalah alat gelas laboratorium (Pyrex), alat penghalus simplisia, plat pemanas

(ThermoScientific), thermometer, oven pengering simplisia, spektrofotometer UV-Vis (Shimadzu, UV Mini 1240).

\subsection{Pembuatan Simplisia}

Kulit nanas yang diperoleh diproses menjadi simplisia melalui beberapa tahapan. Kulit nanas disortasi, dibersihkan 
dengan air mengalir kemudian dikeringkan di dalam oven pada suhu kurang lebih $50^{\circ} \mathrm{C}$. Kulit nanas yang sudah dikeringkan kemudian dibuat menjadi serbuk, disimpan dalam tempat tertutup.

\subsection{Optimasi Metode Ekstraksi Karbohidrat}

Metode ekstraksi yang digunakan merupakan modifikasi dari metode yang dikembangkan oleh Cui et al. (2014). Optimasi metode ekstraksi karbohidrat dari kulit nanas dalam penelitian ini dilakukan sebanyak 2 tahap. Tahap pertama yaitu pada tahap ekstraksi yang dilakukan kondisi yang berbeda, yaitu suhu dan perbandingan antara bahan:pelarut yang digunakan dengan lamanya pemanasan berlangsung selama 1 jam. Optimasi tahap kedua yaitu pada tahap pengendapan polisakarida menggunakan etanol sebagai pengendap dengan konsentrasi yang berbeda. Pada tahap ekstraksi, rancangan yang digunakan adalah rancangan acak lengkap faktorial dua faktor. Faktor pertama adalah suhu dengan empat taraf: $60^{\circ} \mathrm{C}, 70^{\circ} \mathrm{C} .80$ ${ }^{\circ} \mathrm{C}$ dan $90{ }^{\circ} \mathrm{C}$. Faktor kedua adalah rasio bahan pelarut dengan tiga taraf: 1:25, 1:40 dan 1:55. Setiap kombinasi perlakuan diulang 3 kali.

Pada masing-masing tahapan optimasi, dilakukan pengukuran karbohidrat yang terekstraksi menggunakan Metode Fenol-asam sulfat untuk mengukur kadar monosakarida dengan glukosa sebagai pembanding (Nielsen, 2017). Dalam metode ini, dibuat larutan induk glukosa $100 \mathrm{mg} / \mathrm{L}$, kemudian dibuat seri larutan dengan pengenceran menggunakan aquades dengan konsentrasi 0, 20, 40, 60, 80 dan $100 \mu \mathrm{g} / 2$ $\mathrm{mL}$. Larutan sampel dibuat dengan melarutkan 40 mg ekstrak ke dalam $100 \mathrm{ml}$ aquades. Ke dalam larutan pembanding dan sampel ditambahkan larutan fenol (80\%) sebanyak $500 \mu \mathrm{L}$. Setelah itu ke dalam larutan ditambahkan asam sulfat sebanyak $5 \mathrm{~mL}$ melalui dinding tabung lalu diinkubasi selama 10 menit pada suhu $25^{\circ} \mathrm{C}$, kemudian dilakukan pengukuran menggunakan spektrofotometri Uv-Vis pada panjang gelombang $490 \mathrm{~nm}$ dengan membuat kurva kalibrasi dan memplot nilai absorbansi sampel ke dalam persamaan garis lurus. Kadar karbohidrat terekstraksi dihitung sebagai \%, dengan menggunakan rumus berikut:

$$
\begin{aligned}
& Y\left(\%, \frac{b}{b}\right)= \\
& \frac{\text { Berat karbohidrat kulit nanas }(\mathrm{mg})}{\text { Berat serbuk kulit nanas }(\mathrm{mg})} \times 100 \%
\end{aligned}
$$

\subsection{Uji Statistika}

Data dianalisis dengan menggunakan tabel anova dengan menggunakan taraf uji 5\%. Jika hasil anova signifikan, selanjutnya dilakukan pembandingan berganda (multiple comparison) menggunakan metode Tukey dengan taraf uji 5\%. Untuk mendapatkan suhu dan rasio bahan pelarut yang optimal, dilakukan analisis dengan metode permukaan respon. Pemeriksaan asumsi anova dilakukan untuk melihat apakah asumsi anova terpenuhi atau tidak.

Ekstrak yang dihasilkan pada kondisi yang ditentukan dalam analisis respon permukaan dari tahap ekstraksi digunakan untuk menentukan konsentrasi etanol yang optimal. Konsentrasi etanol yang dicobakan adalah 70\%, 83\%, dan 96\%. Hasil ekstraksi dimodelkan dengan menggunakan model regresi kuadratik. Pengujian koefisien regresi dilakukan dengan menggunakan taraf uji 5\%. Dalam analisis regresi ini juga dilakukan pemeriksaan asumsi analisis regresi, yaitu keacakan sisaan, normalitas sisaan, 
homogenitas varian.Asumsi tersebut adalah normalitas sisaan (residual) dan homogenitas varian.

\section{HASIL DAN PEMBAHASAN}

Limbah kulit nanas yang berhasil dikumpulkan, dibersihkan dengan air mengalir, untuk menghilangkan pengotor yang menempel. Bahan ini tidak dirajang terlebih dahulu sebelum dikeringkan dikarenakan bahannya sudah berukuran kecil. Pengeringan dilakukan pada suhu $50^{\circ} \mathrm{C}$ selama \pm 7 hari. Dalam proses pembuatan simplisia ini, dari $8 \mathrm{~kg}$ limbah kulit nanas diperoleh 0,6 kg simplisia sehingga diperoleh rendemen sebesar $7,5 \%$.

Ekstraksi karbohidrat dilakukan pada empat suhu yang berbeda yaitu 60, 70, 80 dan $90{ }^{\circ} \mathrm{C}$, menggunakan pelarut air dengan perbandingan 1:25, 1:40 dan 1:55 terhadap bahan simplisia kulit nanas. Dari hasil tahap ekstraksi ini kemudian dilakukan penetapan kadar karbohidrat terekstraksi menggunakan metode Fenol asam sulfat, yang hasilnya seperti terlihat pada Tabel 1.

Tabel 1. Kadar Karbohidrat Terekstraksi pada Simplisia Kulit Nanas

\begin{tabular}{ccccc}
\hline Rasio & \multicolumn{4}{c}{ Rata-rata Kadar Karbohidrat Terekstraksi } \\
\cline { 2 - 5 } Bahan:Pelarut & $\mathbf{T 6 0 ^ { \circ } \mathbf { C }}$ & $\mathbf{T 7 0} \mathbf{C}$ & $\mathbf{T 8 0}^{\circ} \mathbf{C}$ & $\mathbf{T 9 0}^{\circ} \mathbf{C}$ \\
\hline $1: 25$ & $21,33(\mathrm{D})$ & $25,19(\mathrm{BC})$ & $25,21(\mathrm{BC})$ & $26,22(\mathrm{ABC})$ \\
$1: 40$ & $23,84(\mathrm{CD})$ & $25,59(\mathrm{BC})$ & $29,34(\mathrm{~A})$ & $23,59(\mathrm{CD})$ \\
$1: 55$ & $23,47(\mathrm{CD})$ & $24,24(\mathrm{BCD})$ & $24,14(\mathrm{BCD})$ & $27,27(\mathrm{AB})$ \\
\hline
\end{tabular}

Keterangan: Rata-rata kadar karbohidrat yang tidak memiliki huruf yang sama adalah yang berbeda bermaksna

Data yang diperoleh kemudian dianalisis secara statistika menggunakan ANOVA yang menunjukan bahwa penggunaan suhu dan perbandingan bahan:pelarut memberikan hasil kadar karbohidrat yang berbeda secara signifikan $(P<0,05)$. Dengan demikian terdapat pengaruh dari suhu dan perbandingan bahan:pelarut terhadap kadar karbohidrat yang terekstraksi dari kulit nanas ini. Hasil analisis plot pengaruh masing-masing suhu dan rasio bahan:pelarut terhadap perolehan karbohidrat kulit nanas dapat dilihat pada Gambar 1. 


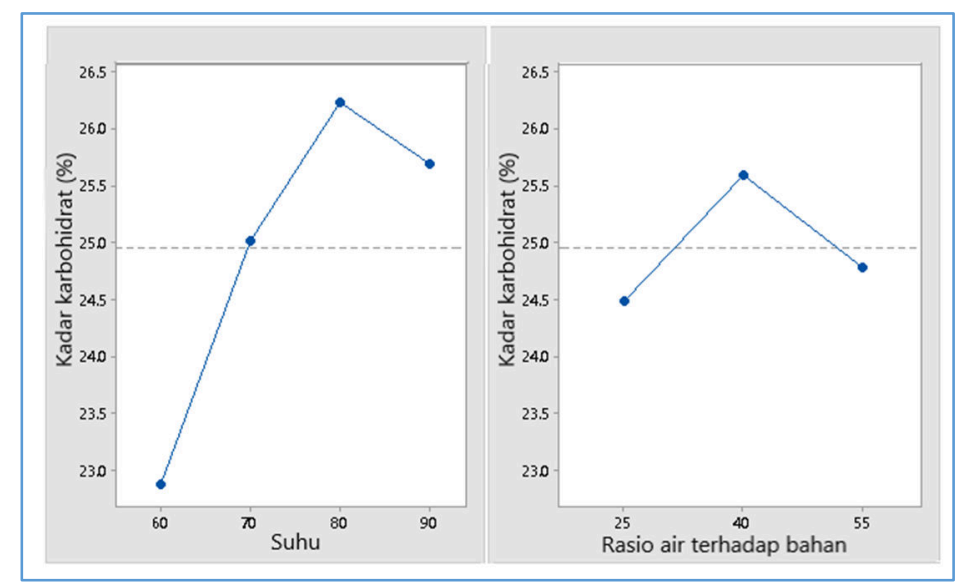

Gambar 1. Hasil analisis plot pengaruh suhu (a) dan rasio bahan:pelarut (b) terhadap perolehan kadar karbohidrat pada kulit nanas

Dari Gambar 1a. dapat dilihat bahwa dengan adanya kenaikan suhu, maka kadar karbohidrat yang terekstraksi juga mengalami peningkatan. Kenaikan suhu pada dasarnya dapat meningkatkan kelarutan senyawa sehingga kadar senyawa terekstraksi meningkat. Kenaikan suhu akan memperbesar jarak antar molekul pada senyawa sehingga senyawa menjadi lebih mudah larut. Selain itu, suhu yang semakin tinggi menyebabkan pergerakan molekul meningkat, sehingga dapat mempercepat dan meningkatkan perpindahan karbohidrat dari padatan ke pelarut (Itsnani, dkk, 2018). Kenaikan suhu juga dapat meningkatkan koefisien difusi karbohidrat sehingga kelarutan polisakarida dalam pelarut juga meningkat (Wang, et.al, 2014). Namun stabilitas senyawa dapat dipengaruhi oleh adanya kenaikan suhu yang dapat mengakibatkan terjadinya dekomposisi sehingga tidak terjadi perubahan pada kadar senyawa terekstraksi. Kemungkinan hal ini yang terjadi ketika suhu ekstraksi dinaikkan menjadi $90{ }^{\approx} \mathrm{C}$, pada suhu tersebut karbohidrat mengalami dekomposisi sehingga jumlah karbohidrat yang terekstraksi menjadi berkurang (Jin, et.al, 2012).

Pada Gambar 1b. tampak bahwa penambahan jumlah pelarut tentu juga akan meningkatkan jumlah karbohidrat yang terekstraksi. Ketika volume air yang digunakan untuk ekstraksi bertambah, maka larutan disekira jaringan tanaman lebih encer yang menyebabkan molekul karbohidrat lebih mudah terdifusi dari dalam sel ke larutan di luar sel yang mengakibatkan kadar karbohidrat yang air akan meningkat (Wang et al., 2014). Pada perbandingan bahan:pelarut dari rasio 1:40 menjadi 1:55, ternyata tidak meningkatkan kadar karbohidrat yang terekstraksi. Hal tersebut kemungkinan disebabkan semua karbohidrat dalam kukit nanas telah terekstraksi, sehingga tidak ada lagi karbohidrat yang berpindah dari serbuk kulit nanas ke air.

Suhu dan rasio air terhadap bahan yang optimal ditentukan dengan menggunakan Metode Respon Permukaan pada Gambar 2, dimana terlihat bahwa semakin tinggi kadar karbohidrat yang terekstraksi ditunjukkan dengan warna yang semakin gelap. 
Kondisi optimal untuk ekstrasi karbohidrat dari kulit nanas berada pada suhu $80^{\circ} \mathrm{C}$ (Gambar 2a) dengan perbandingan bahan: pelarut yaitu 1: 37
(Gambar 2b). pertimbangan teknis, sehingga dalam tahap selanjutnya digunakan pelarut dengan perbandingan 1:40.

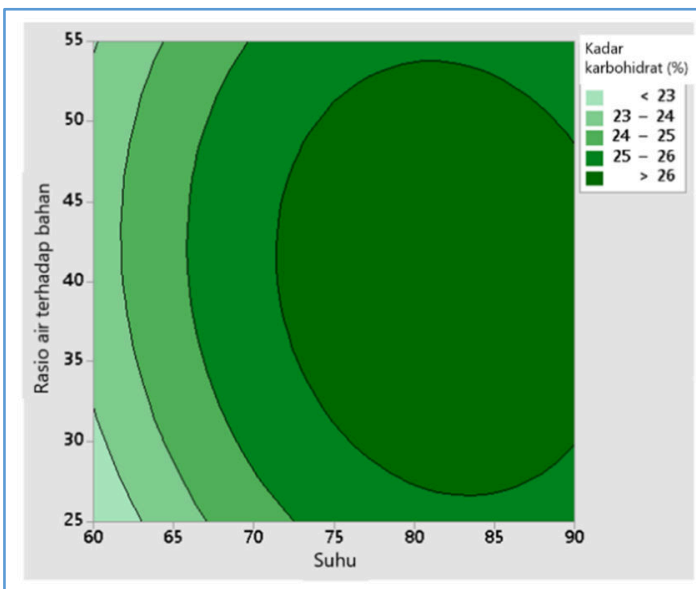

a

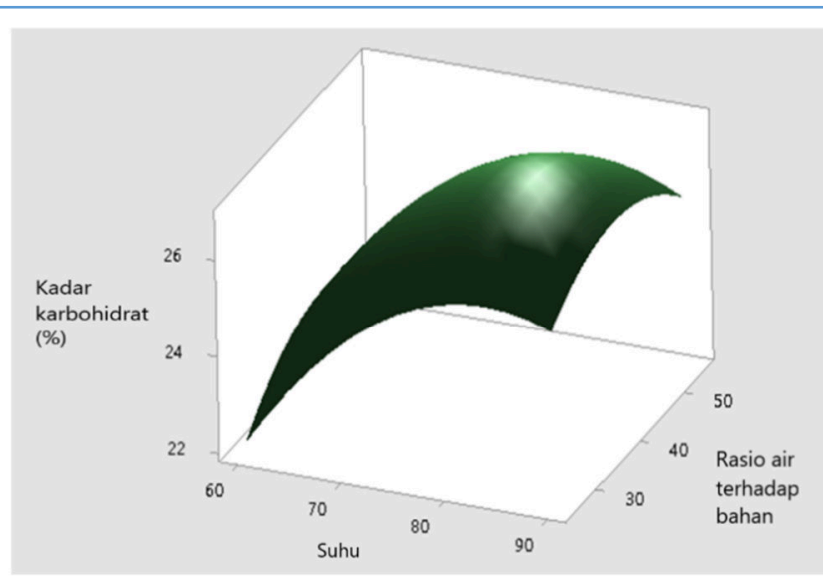

b

Gambar 2. Contour plot suhu (a) terhadap perbandingan bahan:pelarut (b) terhadap perolehan karbohidrat pada kulit nanas

Terhadap ekstrak karbohidrat yang dihasilkan pada kondisi optimal, dilakukan pemisahan polisakarida dengan metode pengendapan menggunakan etanol dengan konsentrasi yang berbeda yaitu: 70, 83 dan 96\% dengan pengulangan sebanyak tiga kali. Kemudian dilakukan kembali pengukuran kadar polisakarida menggunakan metode fenol - asam sulfat. Dari hasil tahap pengendapan ini, analisis plot rata-rata karbohidrat terekstraksi pada konsentrasi etanol diilustrasikan pada Gambar 3.

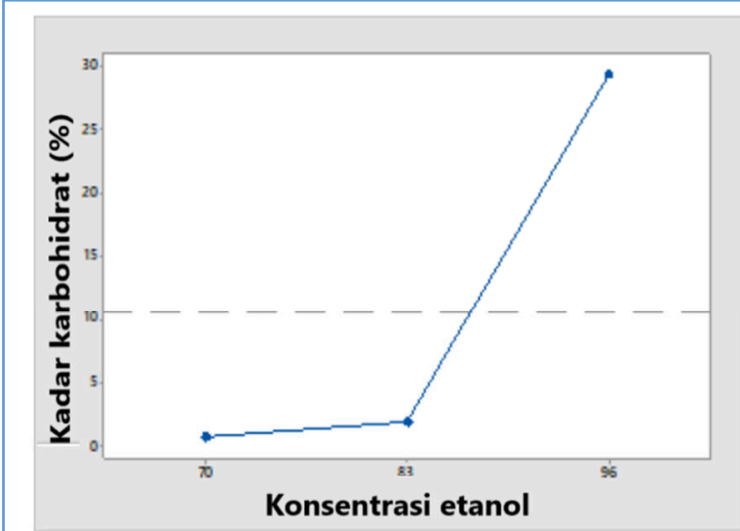

a

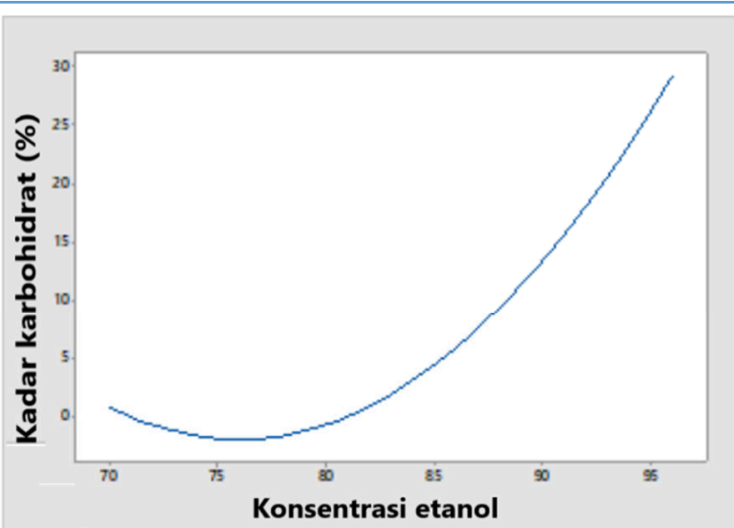

b

Gambar 3. Analisis plot (a) dan hubungan kuadratik (b) konsentrasi etanol sebagai pengendap terhadap perolehan kadar karbohidrat terekstraksi pada kulit nanas 
Dari data yang diperoleh pada optimasi pengendapan, diketahui bahwa pengaruh linier dan kuadrat konsentrasi etanol sebagai pengendap terhadap kandungan karbohidrat pada kulit nanas adalah signifikan baik untuk taraf uji 5\% maupun $1 \%$. Hal ini terlihat dari nilai PValue kedua komponen tersebut yang lebih kecil dari taraf uji. Model yang diperoleh dalam pengujian juga sangat baik dengan $r 2$ sebesar $99.87 \%$. Berdasarkan nilai $r 2$ tersebut maka $99.87 \%$ variasi kandungan karbohidrat dapat diterangkan oleh model kuadratik. Model persamaan kuadratik yang diperoleh dalam penelitian ini adalah sebagai berikut:

$y=447.7-11.841 X+0.07795 X^{2}$

Dari Gambar 3 (b), dapat dilihat bahwa kurva yang dihasilkan berbentuk cekung, sehingga tidak bisa ditentukan titik maksimum sebab jika konsentrasi alkohol diturunkan di bawah $70 \%$ atau dinaikkan dinaikkan di atas 96\%, ada kemungkinan kadarnya akan naik. Akan tetapi pada kisaran konsentrasi etanol yang digunakan dalam penelitian ini, yaitu 70 - 96\%, hasil maksimum yang diperoleh yaitu pada konsentrasi $96 \%$ dengan prediksi kadar karbohidrat terekstraksi sebesar 29.335\%. Dengan tingkat kepercayaan $95 \%$ prediksi kadar karbohidrat terekstraksi pada rentang konsentrasi etanol yang digunakan berkisar antara 27.696 sampai 30.975\%. Pada saat penggunaan etanol dengan konsentrasi yang dinaikkan dari $83 \%$ menjadi 96\%, terlihat bahwa kadar karbohidrat meningkat secara signifikan. Hal ini dapat diakibatkan karena adanya peningkatan konsentrasi etanol sehingga membuat kemampuannya sebagai pengendap juga meningkat.

\section{KESIMPULAN}

Dari hasil penelitian ini, diketahui bahwa optimasi perolehan kadar karbohidrat, dari kulit nanas dapat dilakukan dengan kondisi ekstraksi pada suhu $800 \mathrm{C}$, perbandingan bahan:pelarut 1:37 dan menggunakan pengendap etanol pada konsenstrasi $96 \%$ dengan prediksi perolehan sebesar $29.33 \%$.

\section{UCAPAN TERIMA KASIH}

Penelitian ini didanai oleh Hibah Penelitian Dosen Muda tahun akademik 2020/2021 yang diberikan oleh Lembaga Penelitian dan Pengabdian kepada Masyarakat (LPPM) Unisba dengan nomor kontrak: 099/B.04/LPPM/XH/2020.

\section{DAFTAR PUSTAKA}

Amorim, JC., Piccoli, RH., \& Duarte, WF., 2018, Probiotic potential of yeasts isolated from pineapple and their use in the elaboration of potentially functional fermented beverages, Food Research International, 107(2017), 518-527. https://doi.org/10.1016/j.foodres.2018.02.0 54

Aydar AY., Utilization of Response Surface Methodology in Optimization of Extraction of Plant Materials, http://dx.doi.org/10.5772/intechopen.7369 0

Azwanida, A Review on the Extraction Methods Use in Medicinal Plants, Principle, Strength and Limitation, Med Aromat Plants 2015, 4:3

Azmir, J., Zaidul, I.S.M., Rahman, M.M., Sharif, K.M., Mohamed, A., Sahena, F., Jahurul. M.H.A., Ghafoor, K., Norulaini, N.A.N., Omar, A.K.M, Techniques for extraction of bioactive compounds from plant materials: A review, Journal of Food Engineering 117 (2013) 426-436

Banerjee S, Patti AF, Ranganathan V, Arora A., Hemicellulose based biorefinery from pineapple peel waste: Xylan extraction and 
its conversion into xylooligosaccharides, Food Bioprod Process, 2019;117:38-50.

Buanasari B, Eden WT, Sholichah Al. Extraction of Phenolic Compounds from Petai Leaves (Parkia speciosa Hassk.) using Microwave and Ultrasound Assisted Methods. J Bahan Alam Terbarukan. 2017;6(1):25-31.

Departemen Kesehatan Republik Indonesia, 2000, Parameter Standar Umum Ekstrak Tumbuhan Obat, Departemen Kesehatan Republik Indonesia, Jakarta, Indonesia

Cui, G., Zhang, W., Wang, Q., Zhang, A., Mu, H., Bai, H., \& Duan, J., 2014, Extraction optimization, characterization and immunity activity of polysaccharides from Fructus Jujubae. Carbohydrate Polymers, $111,245-255$.

Diaz-Vela J, Totosaus A, Cruz-Guerrero AE, De Lourdes Pérez-Chabela M., 2013, In vitro evaluation of the fermentation of addedvalue agroindustrial by-products: Cactus pear (Opuntia ficus-indica L.) peel and pineapple (Ananas comosus) peel as functional ingredients, Int J Food Sci Technol, 2013;48(7):1460-7.

Huang YL, Tsai YH, Chow CJ., 2014, Waterinsoluble fiber-rich fraction from pineapple peel improves intestinal function in hamsters: Evidence from cecal and fecal indicators, Nutr Res, 2014;34(4):346-54.

Ingle, KP., Deshmukh AG, Padole DA, Dudhare MS, Moharil MP, dan Khelurkar VC, 2017, Phytochemicals: Extraction methods, identification and detection of bioactive compounds from plant extracts, Journal of Pharmacognosy and Phytochemistry 2017; 6(1): 32-36

Itsnani NS, Widjanarko SB., 2018, Optimasi Proses Ekstraksi Pektin dari Kulit dan Jerami Nangka (Artocarpus heterophyllus) Menggunakan Kurva Respon Permukaan, J Pangan dan Agroindustri. 2018;5(4).

Jayakumar, A., Padmakumar, P., Nair, I. C., \& Radhakrishnan, E. K., 2020, Drought tolerant bacterial endophytes with potential plant probiotic effects from Ananas comosus. Biologia, 75(10), 1769-1778. https://doi.org/10.2478/s11756-020-004831

Jin M, Zhao K, Huang Q, Xu C, Shang P., 2012, Isolation, Structure and Bioactivities of the Polysaccharides from Angelica sinensis
(Oliv.) Diels: A review. Carbohydr Polym. 2012;89(3):713-22.

Kumalasari R., Herminiati A., Andriansyah, RCE., 2015, Pineapple Peel as a Potential Source of Dietary Fiber, Proceeding of International Conference, 1 st International Conference on Appropriate Technology Development

Li X., Wang L., 2016, Effect of extraction method on structure and antioxidant activity of Hohenbuehelia serotina polysaccharides, International Journal of Biological Macromolecules, 83, 270-276

Lourenço SC, Moldão-Martins M, Alves VD., 2020, Microencapsulation of pineapple peel extract by spray drying using maltodextrin, inulin, and Arabic gum as wall matrices, Foods. 2020;9(6):1-17.

Mohammed, ASA, Naveed, M., Jost, M., 2021, Polysaccharides; Classification, Chemical Properties, and Future Perspective Applications in Fields of Pharmacology and Biological Medicine (A Review of Current Applications and Upcoming Potentialities), Journal of Polymers and the Environment, 29:2359-2371

Nielsen, S. S., 2017,Total Carbohydrate by Phenol-Sulfuric Acid Method BT - Food Analysis Laboratory Manual (S. S. Nielsen (ed.); pp. 137-141). Springer International Publishing. https://doi.org/10.1007/978-3319-44127-6 14

Pires, B. de A., Cristina de Almeida Bianchini Campos, R., Canuto, J. W., de Melo Carlos Dias, T., Furtado Martins, E. M., Licursi, L., Ricardo de Castro Leite Júnior, B., \& Martins, M. L., 2020, Lactobacillus rhamnosus GG in a mixed pineapple (Ananas comosus L. Merril) and jussara (Euterpe edulis Martius) beverage and its survival in the human gastrointestinal tract. Lwt, 134(August). https://doi.org/10.1016/j.lwt.2020.110028

RenJie L.. 2008, Optimization of extraction process of Glycyrrhiza glabra polysaccharides by response surface methodology. Carbohydr Polym. 2008;74(4):858-61.

Sabiha Hanim S, Norsyabilah R, Nor Suhaila MH, Noraishah A, Siti Kartina AK., 2012, Effects of temperature, time and pressure on the hemicelluloses yield extracted using 
subcritical water extraction. Procedia Eng, 2012;42(August):562-5.

Sah, B.N.P., T. Vasiljevic, S. McKechnie, O. N. Donkor, 2015, Effect of Pineapple Waste Powder on Probiotic Growth, Antioxidant and Antimutagenic Activities of Yogurt, $J$ Food Sci Technol, DOI 10.1007/s13197-0152100-0

Utomo, PP, 2011, Pemanfaatan Nanas (Ananas comosus) sebagai Bahan Baku Pembuatan Bioetanol dengan Metode Sakarifikasi dan
Fermentasi Serentak, Biopropal Industri, Vol. 102 , No. 01

Wang Y, Liu Y, Hu Y, 2014, Optimization of polysaccharides extraction from Trametes robiniophila and its antioxidant activities, Carbohydr Polym. 2014;111:324-32.

Yeni, G, Gumbira-Sa'id, E., Syamsu, K., Mardliyati, E., 2014, Penentuan Kondisi Terbaik Ekstraksi Antioksidan dari Gambir Menggunakan Metode Permukaan Respon, Jurnal Litbang Industri, Vol.4 No.1, Juni 2014: 39-48.

Copyright $\odot 2020$ The author(s). You are free to Share - copy and redistribute the material in any medium or format. Adapt - remix, transform, and build upon the material. Under the following terms: Attribution - You must give appropriate credit, provide a link to the license, and indicate if changes were made. You may do so in any reasonable manner, but not in any way that suggests the licensor endorses you or your use. NonCommercial - You may not use the material for commercial purposes. ShareAlike - If you remix transform or build upon the material you must distribute your contributions under the same license as the origina No additional restrictions - You may not apply legal terms or technological measures that legally restrict others from doing anything the license permits. 